\title{
Thiolate gates superoxo states
}

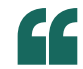

The FGE active site is different to those of well-known Cu oxidase enzymes
Sulfatases are hydrolytic enzymes that prevent the build up of sulfate esters in our bodies, an excess of which can spell death for brain, skeletal and skin cells. Sulfate esters are cleaved by a sulfatase at its geminal diol active site, which is derived from a formylglycine residue (fGly). fGly, in turn, originates from a Cys residue in a reaction catalysed by the formylglycine-generating enzyme (FGE), whose structure and mechanism has long remained unknown. However, a team led by John Tainer, Edward Solomon and Carolyn Bertozzi now describe in the Proceedings of the National Academy of Sciences how the Cu centre in FGE binds a Cys residue in a peptide to trigger $\mathrm{O}_{2}$ attack and the formation of fGly.

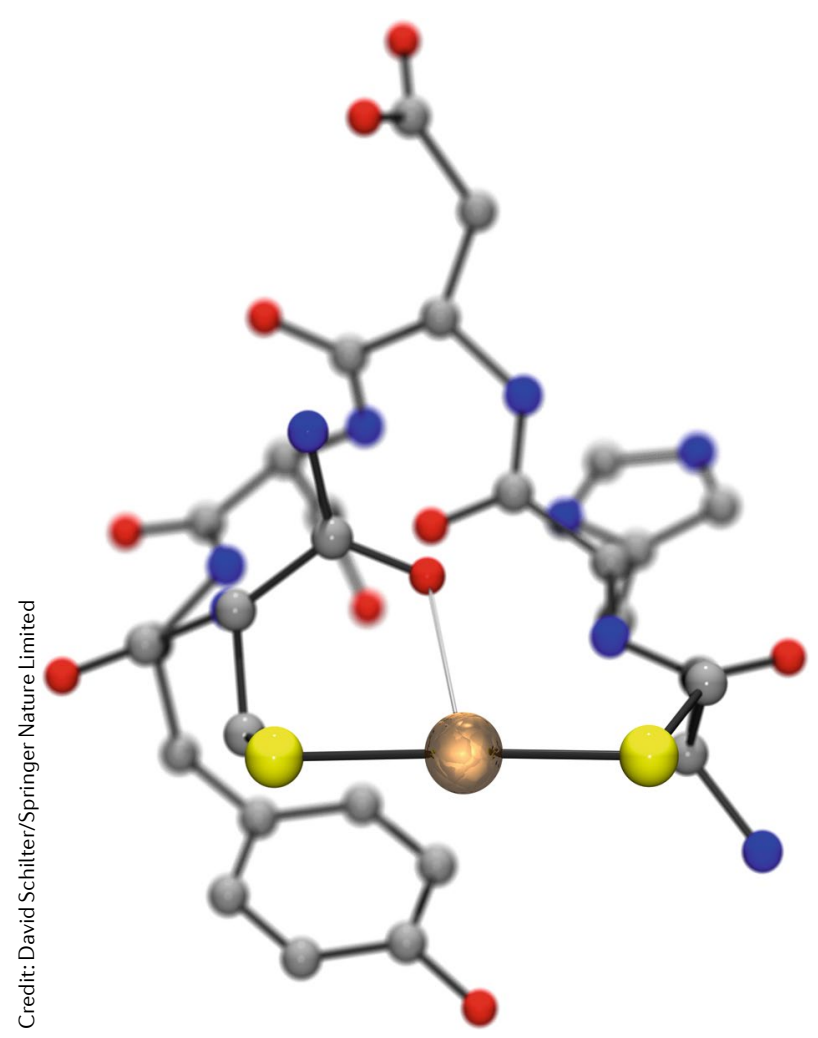

Making a geminal diol $-\mathrm{CH}(\mathrm{OH})_{2}$ from an aldehyde - $\mathrm{CHO}$ is simply a matter of hydration, but how FGE produces - $\mathrm{CHO}$ from the $-\mathrm{CH}_{2} \mathrm{SH}$ side chain of Cys is less clear. Being an oxidation reaction, one might suspect a redox cofactor to be involved, and indeed FGE features $\mathrm{Cu}$ at its active site. Earlier structural studies of apo-FGE and its inactive $\mathrm{Ag}^{\mathrm{I}}$ complex had identified two Cys residues as a potential $\mathrm{Cu}$ binding site. Tainer, Solomon, Bertozzi and colleagues go a step further and characterize the holoenzyme - FGE complete with its native $\mathrm{Cu}^{\mathrm{I}}$ cofactor. Prepared from apo-FGE, $\mathrm{Cu}^{\mathrm{II}}$ and the reductant dithiothreitol, the holoenzyme has a linear $\mathrm{Cu}^{1}(\mathrm{SCys})_{2}$ site that is similar to its $\mathrm{Ag}^{\mathrm{I}}$ congener and typical of $\mathrm{d}^{10}$ metal complexes. With Keith Hodgson and Britt Hedman, the team performed $\mathrm{X}$-ray absorption spectroscopy and extended X-ray absorption fine structure to confirm that the $\mathrm{S}-\mathrm{Cu}^{\mathrm{I}}-\mathrm{S}$ motif also persists in solution. "The FGE active site is different to those of well-known $\mathrm{Cu}$ oxidase enzymes, which feature higher coordination numbers and $\mathrm{N}$-donor and O-donor ligands," says Bertozzi.

Having developed a reliable method to reconstitute the enzyme, the team investigated its binding to Cys-containing peptides. Tainer, Solomon, Bertozzi and co-workers appended a Tyr residue to a Cys-containing sequence in sulfatase to afford a peptide that is a realistic model for the native substrates. To the team's delight, and in contrast to previous studies, this peptide bound FGE strongly enough to afford a stable enzyme-substrate complex under anaerobic conditions. Again, $\mathrm{X}$-ray spectroscopy came to the fore and revealed direct substrate coordination to give the trigonal trithiolate $\mathrm{Cu}^{\mathrm{I}}$ (SCys) $)_{2}$ (peptide$\mathrm{CH}_{2} \mathrm{~S}$ ). In contrast to the linear dithiolate $\mathrm{Cu}^{\mathrm{I}}(\mathrm{SCys})_{2}$, this is sufficiently electron-rich to activate $\mathrm{O}_{2}$ and give the superoxo $\mathrm{Cu}^{\mathrm{II}}(\mathrm{SCys})_{2}$ (peptide- $\left.\mathrm{CH}_{2} \mathrm{~S}\right)\left(\mathrm{O}_{2}{ }^{\bullet}\right)$.

"Substrate binding is likely lowering the redox potential of the $\mathrm{Cu}^{\mathrm{I} / \mathrm{I}}$ couple, thereby enabling the difficult one-electron reduction of dioxygen to give a bound superoxo that can abstract a $\mathrm{H}$ atom from Cys in the substrate," notes Solomon. Intramolecular $\mathrm{H}$ atom abstraction gives the tautomer $\mathrm{Cu}^{\mathrm{II}}(\mathrm{SCys})_{2}$ (peptide- $\left.{ }^{\circ} \mathrm{CHS}\right)(\mathrm{OOH})$, a peroxo that eventually liberates thioaldehyde peptide-CHS, which undergoes hydrolysis to give the fGly product peptide-CHO.

That $\mathrm{O}_{2}$ activation only occurs when $\mathrm{Cu}^{\mathrm{I}}(\mathrm{SCys})_{2}$ binds the peptide reflects nature's careful control over $\mathrm{O}_{2}$ reactivity. For example, if $\mathrm{Cu}^{\mathrm{I}}(\mathrm{SCys})_{2}$ itself were to first bind $\mathrm{O}_{2}$, then FGE might engage in promiscuous reactions and cause oxidative damage. What remains unclear is how, after product formation, the resulting peroxo $\mathrm{Cu}^{\mathrm{I}}(\mathrm{SCys})_{2}(\mathrm{OOH})$ undergoes reduction to $\mathrm{Cu}^{\mathrm{I}}$ (SCys) ${ }_{2}$ to complete the cycle. Although there is still work to be done, the study of Tainer, Solomon, Bertozzi and colleagues arms us with the knowledge to prepare antibodies with fGly functional handles and better understand diseases such as multiple sulfatase deficiency.

David Schilter

ORIGINAL ARTICLE Appel, M. J. et al.

Formylglycine-generating enzyme binds substrate directly at a mononuclear $\mathrm{Cu}(\mathrm{I})$ center to initiate $\mathrm{O}_{2}$ activation. Proc. Natl Acad. Sci. USA. https://doi. org/10.1073/pnas.1818274116(2019) 